\title{
Early life distribution of gold spotted grenadier anchovy Coilia dussumieri valenciennes, 1848 at ye river estuary, southern mon coastal water
}

\begin{abstract}
The pattern of the use of the Ye River Estuary, euryhaline area in southern Mon coastal water, by Coilia dussumieri was investigated to assess spawning period, recruitment and to detect spatial-temporal patterns of this major fishery resource. Fishes were sampled by seine nets, from early premonsoon, 2013 to postmonsoon, 2014 and by beach seine, from premonsoon, 2013 to postmonsoon, 2015. Reproductive season, measured in terms of GSI, gonad development and appearance of recruits, indicate that reproduction occurs from August to March, when they reach the best condition. Recruitment peaks in post and pre-monsoon at sandy beaches where they stay until early monsoon, moving toward deeper estuary areas during late monsoon. After that, they join adults and perform movements between the estuary and the adjacent continental shelf to reproduce.
\end{abstract}

Volume 7 Issue 2 - 2018

\author{
Naung Naung Oo \\ Department of Marine Science, Mawlamyine University, \\ Myanmar
}

Correspondence: Naung Naung Oo,Assistant Lecturer, Department of Marine Science, Mawlamyine University, Myanmar, Email naungnaungoomarine@gmail.com

Received: March 24, 2018| Published: April 25, 2018

Keywords: anchovies, condition, Engraulidae, recruitment, reproduction

\section{Introduction}

Fishes of the Engraulidae family, known as anchovies, are widely distributed in tropical and sub-tropical waters. ${ }^{1}$ Most anchovies species spawn in open coastal areas in the inner continental shelf, and the juveniles recruit in protected shallow areas, which offer food and shelter against predators. ${ }^{2}$ As adults, they move, on a diel and seasonal basis, between open coastal areas and bays, concentrating in large schools, when they become vulnerable to commercial fisheries. ${ }^{3}$

In Ye River Mouth, a euryhaline estuarine area in southern Mon State (Lat. $15^{\circ} 04^{\prime} \mathrm{N}$, Long. $97^{\circ} 46^{\prime} \mathrm{E}$ ), Coilia dussumieri Valenciennes, 1848 rank among the most abundant fishes either, as juveniles recruiting at sandy beaches, or as adults occupying deeper areas in the estuary. Coilia dussumieri has supported important subsistence and commercial fisheries, as well as being a major prey item for several other fish species. In recent years their stocks have declined to the point that the fishery has been severely affected. ${ }^{4}$ One of the most critical periods in the recruitment process of this species is the survival of recruits in deteriorated areas of Ye River Estuary. Aspects of the reproductive biology and recruitment of C. dussumieri in the Ye River Estuary are unknown. The fishery of C. dussumieri occurs between late winter and summer, when adults come into the estuary or bay. ${ }^{5}$ In tropical areas the closed related ramcarat anchovy, C. ramcarati (Hamilton-Buchanan, 1822) is a serial spawner and has a reproductive season during spring/summer when virtually all females spawn at night. ${ }^{3}$

Evidence to date appears to indicate that anchovies form welldefined shoals in the lower half of the water column during the day for feeding purposes; at night, anchovy shoals spread out considerably. ${ }^{6}$ The fishing of $C$. dussumieri within the Ye River Estuary occurs during daylight when the fish are feeding. This is probably associated with the vertical migration of plankton, when shoals are more concentrated.

The main purposes of this study are: 1) to examine the strategy of use of the C. dussumieri in Ye River Estuary, 2) to investigate the spawning period was related to the juvenile recruitment at sandy beaches, 3) to know the early life stages were assessed to detect eventual spatial-temporal pattern, and 4) to examine the length frequency distribution of $\mathrm{C}$. dussumieri occupying two estuarine areas, Ye River Mouth in Mon coastal water.

\section{Materials and methods}

\section{Study area}

Ye River Estuary (Figure 1) is a sedimentary and euryhaline environment, which originated by an extensive process of sand deposition that formed a barrier beach at its southern bound. It has a wide communication with the Andaman Sea on its southern boundary. The estuary shows a mean depth of $8.6 \mathrm{~m}$ and a maximum depth of $30 \mathrm{~m}$. Waters are predominantly euryhaline (average salinity $=30 \%$ ). The annual rainfall is between 250 and $3,780 \mathrm{~mm}$ (Meteorology Department, Ye Township) but this does not influence the estuary salinity due to the existence of small tributaries only. Most of the substrate is silt and mud. The tidal range is approximately $1.5 \mathrm{~m}$. Predominantly north-easterly and south-westerly winds activate warm currents between the estuary and the sea.

Two estuarine zones were arbitrarily defined to maximize variation in habitat characteristics, including depth, salinity, transparency, temperature and influences of human activities. The outer zone has a sandy and gravel bottom and was close to the sea limit (highest salinity, transparency, depth and lowest temperature); the inner zone, with opposite oceanographic conditions, has a heavy mud bottom and was located within a protected area of the estuary, near to anthropogenic influences from urban wastes.

\section{Sampling}

Two fish sampling programmes were accomplished, one using beach seine nets (10m long, $2 \mathrm{~m}$ deep beach seine with $7 \mathrm{~mm}$ mesh) to catch early juveniles, and other using seines to catch adults in the deeper areas of the estuary. Beach seine were performed monthly, 
from February 2013 to January 2015, at five sites, during the day. The net was pulled through the water parallel to the shore $(1.5 \mathrm{depth})$ for a distance of $30 \mathrm{~m}$ and then onto the shore. Three replicates seines were performed at each site. Samples were carried out in site 1,2 and 3 (outer zone) and sites 4 and 5 (inner zone).

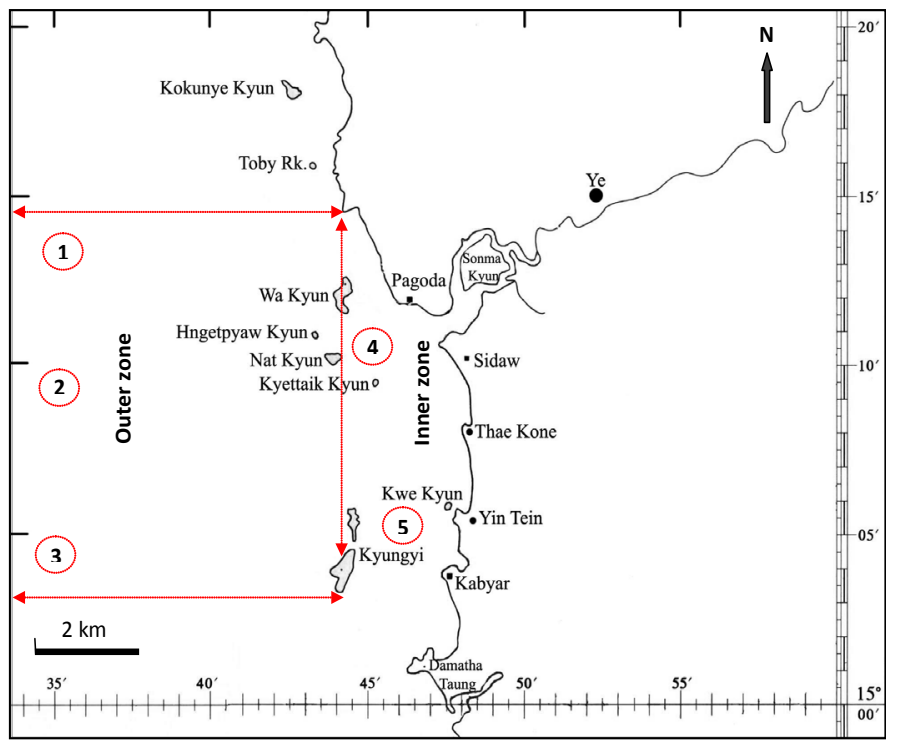

Figure I Map showing the collection sites of $C$. dussumieri (Valenciennes, 1848) in Ye River Estuary, southern Mon coastal water. Symbol: = 3 sampling site.

Seine netting in deep areas adjacent to central estuarine islands (limit between outer and inner zones) was carried out using a $15 \mathrm{~m}$ long boat provide with acoustics echo sounder Royal RV400 equipment to monitor fishing procedure. Samplings were performed monthly from February 2013 to January 2014. The net was $240 \mathrm{~m}$ long, $27 \mathrm{~m}$ deep with an $8 \mathrm{~mm}$ stretch mesh size in the middle-upper half and $10 \mathrm{~mm}$ stretch mesh size in the middle-lower half. The net was released with the help of a small auxiliary boat, while the main fishing boat encircled the schooling, closing the net. Total catches (by numbers and weight) and the length-frequency distribution were recorded for each tow. Sub-samples from very abundant catches were made.

\section{Reproduction}

From the fixative-preserved ovaries, histological sections were prepared. Tissue was sectioned at $5-6 \mu \mathrm{m}$ and stained with haemotoxylin and eosin. Each slide was examined at x100 magnification and classified according to the most advanced stage of oocyte development, the level of atresia and the presence or absence of post-ovulatory follicles.

The oocytes were classified as 1) unyolked; 2) partially yolked; 3 ) advanced yolked; and 4) with migratory nucleus or hydrated. The relative abundance of $\alpha$-atretic to advanced yolked oocytes was also noted. Each ovary was examined histologically and classified (Table 1) (Figure 2). Stages maturation as well as juveniles and adults were separated according to the macroscopy scale proposed by Vazzoler ${ }^{7}$ and confirmed by histological observations.

The Fulton condition index $\left(\mathrm{BWxBL}^{-3}\right)$, where $\mathrm{BW}=$ body weight and $\mathrm{BL}=$ body length, was calculated on a monthly basis. The gonadosomatic index was calculated as $\left(\mathrm{GWxBW}^{-1}\right) \mathrm{x} 100$, where $\mathrm{BW}=$ wet body wt. $(\mathrm{g})$ and $\mathrm{GW}=$ wet gonad wt. $(\mathrm{g})$.

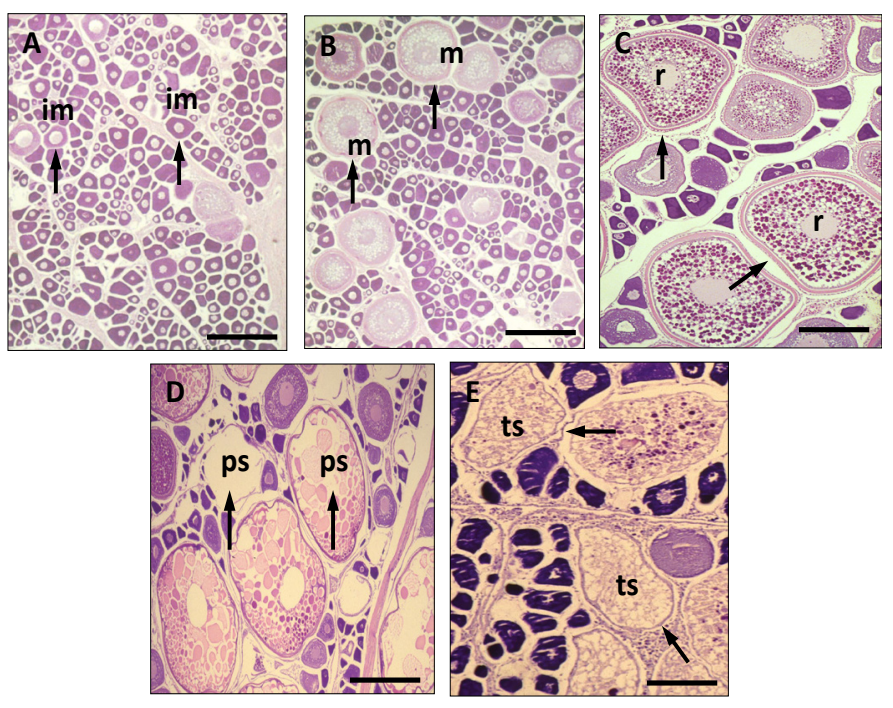

Figure 2 Micrographs from ovaries of Gold spotted grenadier anchovy Coilia dussumieri specimens from Ye River Estuary, southern Mon coastal water in different reproductive conditions.

(A) Ovary showing only unyolked oocytes at the immature stage; (B) Ovary with partially yolked oocytes at the mature stage; (C) Ovary with fully yolked oocytes at the ripe stage; (D) Ovary from an individual in spawning condition with hydrated oocytes; (E) Ovary from an individual in spawning condition showing unyolked and yolked oocytes.

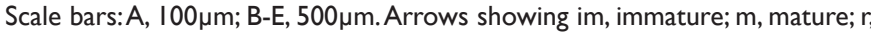
ripe; ps, partially spent; ts, totally spent of oocytes.

Table I Microscopy description of gonad maturation stages for females $C$. dussumieri in the Ye River Estuary in southern Mon coastal water.

\begin{tabular}{ll}
\hline Stages & Characteristics \\
\hline $\begin{array}{l}\text { I. Immature/ } \\
\text { recovering }\end{array}$ & Only oocytes I and 2 \\
$\begin{array}{l}\text { 2. Mature } \\
\text { Mostly oocytes 2 and 3 } \\
\text { Oocytes I, 2, 3 and 4, with the latter being more } \\
\text { numerous }\end{array}$ \\
$\begin{array}{l}\text { 4a. Partially spent } \\
\text { Oocytes I, 2, 3 and 4, empty follicles }\end{array}$ \\
\hline
\end{tabular}

\section{Results}

Gold spotted grenadier anchovy Coilia dussumieri Valenciennes, 1848 in Ye River Estuary, southern Mon coastal water

\section{Systematic classification}

Phylum: Chordata

Class: Actinopterygii (Bony fish)

Order: Clupeiformes

Family: Engraulidae

Genus: $\quad$ Coilia

Species: C. dussumieri (Valenciennes, 1848)

\section{Diagnostic characters}

Body tapering, abdomen rounded anterior to pelvic fins; abdomen 
with keeled scutes beginning only immediately posterior to pectoralfin base and continuing to anus; 5 or 6 (rarely 4) prepelvic and 7 to 9 post pelvic scutes; total number of scutes 12 to 15 . A small spinelike scute just anterior to dorsal-fin origin. Maxilla short, not quite reaching posteriorly to margin of gill cover. Two supramaxillae present; first elongate. Jaw teeth small. Gill rakers fairly short, their serrae not clumped; lower gill rakers 23 to 26 . Branchiostegal rays 10 to 12 (rarely 9 ).

Dorsal fin far forward, beginning in first third of body length. Anal fin long, with 80 or more fin rays; posterior most fin ray joined to caudal fin. Caudal fin very small, extremely pointed. Pectoral fins with upper VI fin rays unbranched, long and filamentous, reaching posteriorly at least to anal-fin origin, and with 9 to 11 (rarely 8) branched fin rays, longer than those of pelvic fins and reaching posteriorly at least to pelvic-fin origin. Pelvic fins with I unbranched and 6 branched fin rays. Isthmus entirely scaled. Striae on anterior part of scales on flanks sparsely reticulated, with many longitudinal striae anteriorly.

\section{Colour}

Dorsum brown, flanks silvery; flanks and abdomen with longitudinal rows of golden or pearly spots (light organs, with a pocket for luminous material and a silvery reflector below) below scales, also along isthmus, along border of lower jaw, and a few on cheek and gill cover (the disposition of the light organs varying a little between individuals) (Figure 3).

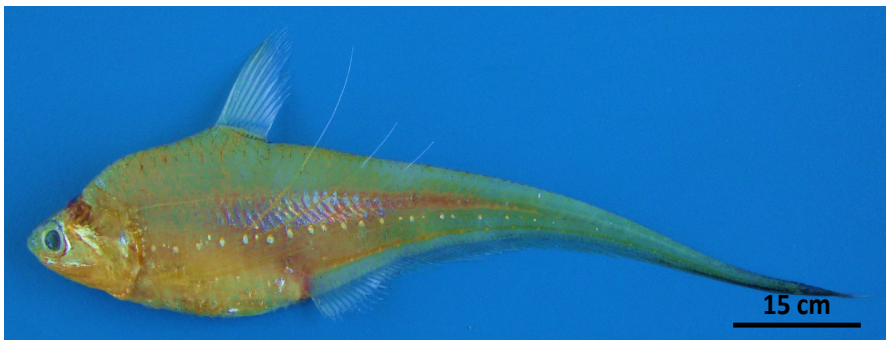

Figure 3 Photograph showing the natural habit of Coilia dussumier (Valenciennes, 1848).

\section{Size}

Maximum standard length presumably $20 \mathrm{~cm}$, commonly between 13 and $17 \mathrm{~cm}$ total length.

\section{Habitat, biology, and fisheries}

Coastal and estuarine, in fully saline water, but also able to tolerate lowered salinities, perhaps almost fresh water. Feeds on copepods, prawn and fish larvae, various unidentified crustaceans and cypris, also stomatopod larvae, mysids, polychaete larvae, isopods, and Sagitta. Breeding season protracted over entire year. Spawning and nursery grounds located inshore of $40 \mathrm{~m}$ isobath. Premonsoon months (March to May) are peak spawning and recruitment season (May to June) in India. Females mature at 6 or 7 months, and $12 \mathrm{~cm}$ total length. Individual females may spawn twice each year with duration between successive spawnings a maximum of 6 months. Fecundity 100 to $5000 \mathrm{eggs} /$ female (females 15.7 to $19 \mathrm{~cm}$ total length). Separate statistics not reported for this common species. Appreciable numbers present in coastal waters and at mouths of estuaries in certain regions. Caught mainly with fixed bagnet beach seines, purse seines, bamboostake traps; also incidentally with bottom trawls. An important food item locally. Marketed fresh, dried, dried-salted or made into fish sauce or fish balls.

\section{Geographical distribution}

Western Central Pacific (Thailand to Java, presumably also Kalimantan) and Indian Ocean (coasts of India from Bombay to Calcutta, probably also Myanmar, Thailand, and Malaysia). ${ }^{3,5}$

\section{Local distribution}

Koe-tae-su (Kyaik-hto), Zot-ka-li (Belin), Aung-kan-tha (Thahton), Ahlyat and Mottama (Paung), Mu-pon and Kyauk-tan (Mawlamyine), Bilugyun (Chaung-zone), Ka-don-paw (Mu-don), Kyaikkhami, and Setse (Than-byu-zayat) and Ye River Mouth areas (present study).

\section{Size structure of beach seines}

Size of individuals ranged from 18 to $112 \mathrm{~mm}$ Total Length (TL), with highest numbers between 22 and $56 \mathrm{~mm} \mathrm{TL}$.

Monthly length-frequencies indicate that a wide recruitment period for C. dussumieri occur in the Ye River Estuary. In the outer estuarine zone, young-of-the-year appeared in early premonsoon 2013 (18-30 $\mathrm{mm}$ TL) reaching in late premonsoon 2013/2014 a size $36-46 \mathrm{~mm}$ TL; during early postmonsoon 2014 they were not recorded in the samples. Another cohort (18-40 mm TL) appeared in postmonsoon 2014 (mode $=26 \mathrm{~mm} \mathrm{TL}$ ), reaching $28-50 \mathrm{~mm}$ TL in premonsoon $2014 / 2015$, and again disappearing from the beach samplings in early postmonsoon 2015 .

In the inner estuarine zone, young-of-the-year appear in early premonsoon 2013 (18-28 $\mathrm{mm}$ TL), reaching $24-30 \mathrm{~mm}$ in premonsoon 2013/2014. They were not recorded during late monsoon, reappearing in large numbers in postmonsoon 2014, showing size ranging 50-62 mm TL. Juveniles from late postmonsoon 2013 showed a comparatively smaller size than juveniles from late postmonsoon 2014, suggesting an earlier reproductive season in the second yearly period. Overall, individuals recorded in premonsoon showed highest size when compared with other seasons.

\section{Size structure of Seine}

Size of the captured individuals ranged from 76 to $120 \mathrm{~mm}$ TL, peaking at 100 and $116 \mathrm{~mm}$. The smallest individuals were common during postmonsoon with modes of approximately $84 \mathrm{~mm}$ TL. Higher abundance occurred in monsoon when compared to postmonsoon.

\section{Reproductive season}

Of 330 ovaries examined, the majority showed advanced maturation stage, being common from August to March; ovaries showing immature/recovering stages were frequent from April to July (Figure 4). In September about $40 \%$ of the females showed early spawning stage. Average GSI values increased from August to February peaking at September. Lower values were recorded from April to June (Figure 5). Fulton fish condition showed highest values from September to February and lowest in June (Figure 6). 


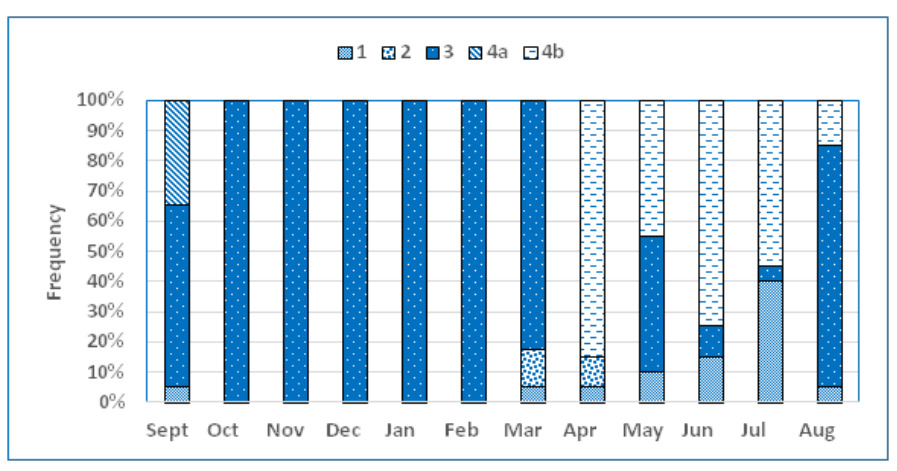

Figure 4 Monthly relative frequency (\%) of gonad stages for females Coilia dussumieri in Ye River Estuary, southern Mon coastal water.

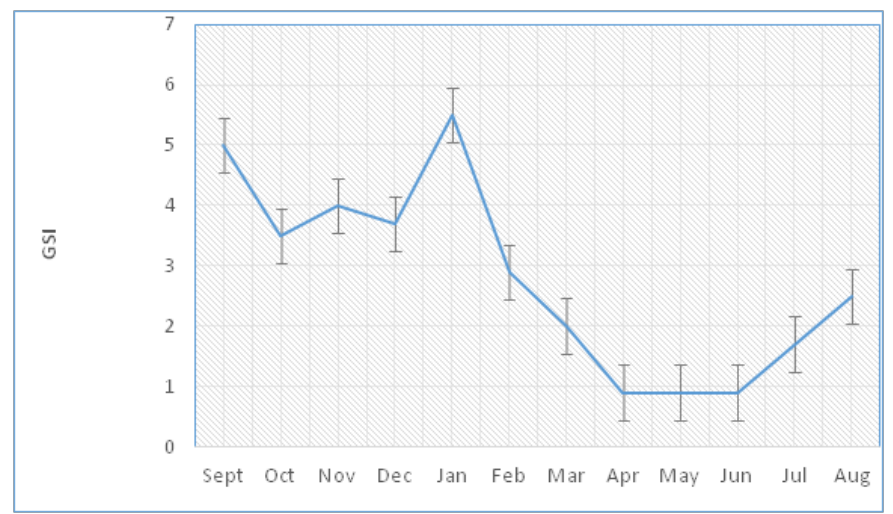

Figure 5 Means gonadosomatic index and standard errors for Coilia dussumieri in Ye River Estuary, southern Mon coastal water.

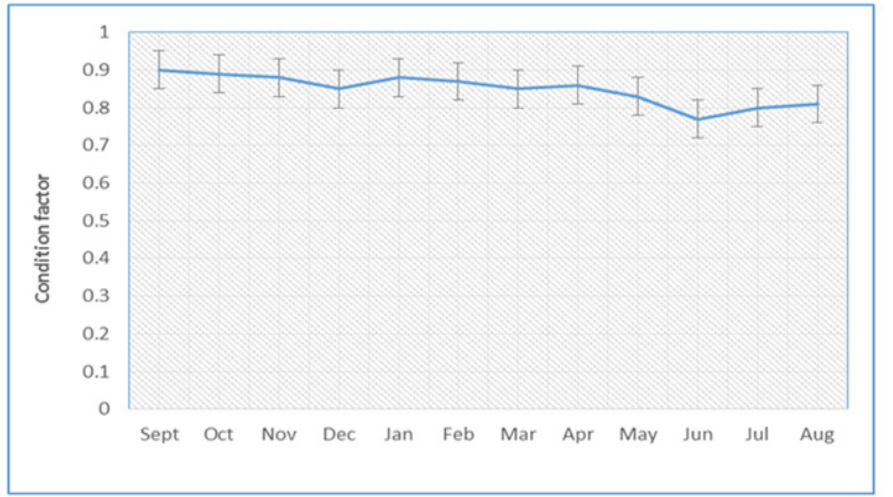

Figure 6 Mean condition factor and standard errors for Coilia dussumieri in Ye River Estuary, southern Mon coastal water.

\section{Discussion}

Coilia dussumieri probably spawns in the adjacent coastal area to the Ye River Estuary, since it has been reported to distribute in most saline estuarine areas, moving between the outer zone and the coastal shelf. ${ }^{8}$ Most members of the Engraulidae family are reported to spawn in coastal zones and their eggs and larval phases enter estuaries and bays where they find protection and food availability. ${ }^{2,9}$ This could be a strategy for $C$. dussumieri to optimise recruitment at a sandy beach in the estuary, by getting close to recruitment areas minimizing high mortality rates in this critical period as eggs, larvae and young- of-the-year. Predominant ocean currents that penetrate the Ye River Estuary on the west side could transport eggs and larvae contributing to the high recruitment rate at the sandy beach in the outer estuarine zone. Waters parcels entering Ye River Estuary were reported by Tin $\mathrm{Nu} .{ }^{10}$ Since the early eighties the importance of sandy beaches in Ye River Estuary was reported by Lwin Lwin \& Tin $\mathrm{Nu}^{10,11}$ that ranked Engraulidae among the most abundant group of fish at beach seines, especially those located at the outer estuarine zone, where conditions are close to the adjacent sea, and anthropogenic influences are comparatively low. Many years later, Su Su Hlaing ${ }^{12}$ recorded this family as the second most abundant group of fishes at the same beaches, confirming the important role of these beaches.

Shoals formations are mechanisms for individual protection against predation. Some shoals performed vertical migration, moving to deeper areas during daylight hours, and dispersing at night, following plankton upward vertical migration. ${ }^{13}$ As a consequence, fishing occurs during the day, since at night there is not enough fish concentration to justify commercial investment, due to their spread out distribution. In Ye River Estuary this pattern is found since fishing occurs only during daylight hours and takes place in deeper areas near island formations. ${ }^{14}$

Coilia dussumieri is a serial spawner with reproductive season from August to March, and this coincides with the increasing photoperiod in Ye River Estuary watershed area. The occurrence of ripe individuals between October and February that contain eggs in different development stages (Oocytes 1, 2, 3 and 4, with the latter being more numerous) is an indication that serial spawn occurs. Raising temperature in this period probably increases zooplankton availability favoring larvae development. It was found that organic and inorganic nutrient loads brought into the estuary by tributaries and drainage channels, favour larvae and juvenile development. ${ }^{2}$ Castrow and Cowen ${ }^{15}$ found a correlation between $C$. dussumieri and copepod nauplius concentrations, and related the survival of anchovies to nauplius concentration. Another explanation is that the adults spawn in direct response to temperature and photoperiod, as suggested by Zastrow et al. ${ }^{16}$ and that the association between older larvae and their prey occurs as the result of spatio-temporal variability in survival of first-feeding larvae.

The relatively high gonadosomatic index (GSI) found between August and March suggests a wide spawning period between late winter and late summer, and a recovering period between April and June. Unexpectedly, only few early recruits (TL $<30 \mathrm{~mm}$ ) were recorded in summer which seems to be the final stage of the reproductive period; such early recruits are common in winter/spring. Spawns probably begin in winter in spite of relatively low GSI, which is influenced by large numbers of individuals with 76-92 $\mathrm{mm}$ TL that join adults in deeper bay areas. Furthermore, no information is available on temporal occurrence of eggs and larvae and how long they take to reach the recruitment size. Fish condition was at the highest between September and February overlapping with GSI peaks.

Condition, according to Vazzoler \& Vazzoler ${ }^{17}$ enables the assessment of variation in the overall health of the species, dictated by several factors, among them, feeding availability. The highest condition recorded between September and February suggests that better feeding conditions in this period allowed reserve tissue concentration and consequently the best physiological condition. The best condition for $C$. dussumieri during the spawning season 
coincides with the hypothesis that this species spawns in a period of high food availability. In spite of Vazzoler \& Vazzoler ${ }^{17}$ considering the spawning period as a time of high energetic loss, and consequent low condition, this was not observed for C. dussumieri in Ye River Estuary. Hunter and Leong 1981 indicate that most of the energy required for spawning has to be obtained from the food consumed during the spawning period itself. ${ }^{18}$

Growth of clupeoids in tropical waters is faster and the life cycle is shorter when compared to temperate areas. Engraulis ringens Jenyns, 1842, a very common species off the Peruvian coast, survives up to eighteen months and this lifetime period is remarkably shorter when compared to the Engraulis mordax Girard, 1854 population off the California coast that reaches up to 5 or 6 years. ${ }^{13}$ In Ye River Estuary, C. dussumieri spent almost one year at the sandy beaches, moving toward deeper areas during early postmonsoon. After that they reach a size of 76-92 $\mathrm{mm}$ TL and join adults in deeper estuarine areas when they are supposed to move between the outer estuary and the continental shelf to reproduce. A part of small sized individuals (50-62 $\mathrm{mm}$ TL) return from the deep estuarine areas to the beaches in postmonsoon joining the recruits (Figure 7). ${ }^{19-23}$

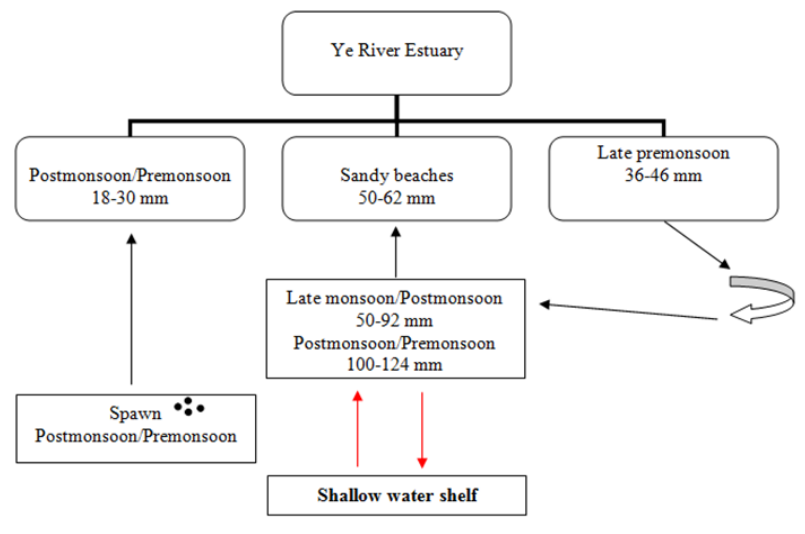

Figure 7 Diagram for life cycle of Coilia dussumieri in Ye River Estuary, southern Mon coastal water. Black arrows correspond to recruits and juveniles; Red arrows correspond to adults.

\section{Conclusion}

In Ye River Estuary, individuals recruited in early premonsoon with 18-30 mm TL reach 36-46 mm TL in premonsoon in the outer estuary, and only 24-30 $\mathrm{mm}$ TL in the inner estuary. The small sample size in premonsoon 2013/2014 in the inner zone is insufficient to support a robust inference on growth. Between-year changes in recruitment and growth rate could also occur. In 2013/2014 reproduction could have occurred later than in 2014/2015, as indicated by the different size of early recruits in premonsoon. In late monsoon, no recruits were recorded at beaches suggesting a movement away from this area in this period. Another hypothesis is that high mortality in this period could occur and explain the absence of fish in this season. Overall a hypothesis for $C$. dussumieri early life cycle can be drawn from the above results. Adults penetrate into the estuary in postmonsoon, spawning near to the estuary connection with the sea, and youngof-the-year are brought to outer estuary sandy beaches by incoming currents favoring recruitment. Young-of-the-year spend almost the first year at sandy beaches, then move away to deeper areas in the estuary, which are used as rearing grounds. After two years old $(>110$ $\mathrm{mm} \mathrm{TL}$ ) they join adults migrating to the continental shelf.

\section{Acknowledgements}

I am indebted to Dr. Aung Myat Kyaw Sein, Acting Rector; Dr. Mie Mie Sein and Dr. San San Aye, Pro-rectors of Mawlamyine University, for their encouragement and support in preparing this work. I am very grateful to Professor Dr. San Tha Tun, Head of Marine Science Department, Mawlamyine University, for his invaluable guidance and literature provided. I also thank to local fishers from Ye River Mouth region, for their helpful assistance in this study.

\section{Conflict of interest}

The author declares no conflict of interest.

\section{References}

1. Mc Gowan MF, Berry FH. Clupeiformes: Development and Relationships. In Ontogeny and Systematics of Fishes. Am Soc Ichthyol. Herpetol. 1983;108-126.

2. Mac Gregor JM, Houde ED. Onshore- Offshore pattern and variability in distribution and abundance of bay anchovy Anchoa mitchilli eggs and larvae in Cheasapeake Bay. Mar Ecol Prog Ser. 1996;138:15-25.

3. Wongratana T, Munroe TA, Nizinski MS. FAO species identification guide for fishery purposes. In: Carpenter KE, Niem VH editors. The living marine resources of the Western Central Pacific. Batoid fishes, chimaeras and bony fishes part 1 (Elopidae to Linophrynidae). FAO, Rome. 1999;3:1397-2068.

4. DoF. Fishery statistics (2007-2008). Ministry of Livestock and Fisheries, Myanmar. $91 \mathrm{p}$.

5. Whitehead PJP, Nelson GJ, Wongratana T. FAO species catalogue Clupeoid fishes of the world. An annotated and illustrated catalogue of the herrings, sardines, pilchards, sprats, shads, anchovies and wolfherrings. Part 2. Engraulididae. FAO Fish. Synop. 1988;7(125):305-579.

6. Tudela S, Palomera I. Trophic ecology of the European anchovy Engraulis encrasilocus in the Catalan sea (northwest mediterranean). Mar Ecol Prog Ser. 1997;160:121-134.

7. Vazzoler, AEAM. Biologia da reprodução de peixes Teleósteos: Teoria e Prática. São Paulo, SBI CNPq/Nupelia (UEM). 1996. 122 pp.

8. Su Su Hlaing, Cho Cho Latt, Tha Zin Aye, et al. Some aspects of the biology of anchovies (Engraulidae) in Setse and Zeephyuthaung coastal areas. Mawlamyine Universitiy Research Journal. 2014;6(1):213-237.

9. Coto CF, Luna AO, Calvo AL, et al. Abundancia de algunas especies de Anchoas en la laguna de Términos (México), estimada a través de la captura de huevos. An. Inst. Cienc. Mar Limnol. Univ. Nac. Auton. Mex. 1987;15(1):125-134

10. Tin Nu. Study on the spat fall of Pena viridis (Linnaeus) in Ye River, Mon State, Burma. Unpublished MSc Thesis. Department of Marine Biology, Moulmein Degree Collage, Burma. 1985.

11. Lwin Lwin. Study on the spat fall of Crassostrea blecheri in Ye River, Mon State, Burma. Unpublished MSc Thesis. Department of Marine Biology, Moulmein Degree Collage, Burma. 1985.

12. Su Su Hlaing. Fishery biology of anchovy (Family Engraulidae) from Mon coastal waters. Unpublished PhD Dissertation. Department of Marine Science, Mawlamyine University, Myanmar. 2016.

13. Lowe-Mcconnell RH. Ecological studies in tropical fish communities. Cambridge University Press. 1988. 382 p. 
14. Tint Swe. Biology and economic of fishery resources caught by stationary bagnets along the coast of Mon State. Unpublished PhD Dissertation. Department of Marine Science, Mawlamyine University, Myanmar. 2011.

15. Castrow L, Cowen RK. Environmental factors affecting the early life history of bay anchovy Anchoa mitchilli in Great South Bay, New York. Mar Ecol Prog Ser. 1991;76:235-247.

16. Zastrow CE, Houde ED, Morin LG. Spawning, fecundity, hatch-date frequency and young-of-the-year growth of bay anchovy Anchoa mitchilli in mid-Chesapeake bay. Mar Ecol Prog Ser. 1991;73:161-171.

17. Vazzoler AEAM, Vazzoler G. Relation between condition factor and sexual development in Sardinella aurita (Cuv and Val 1847). An. Acad Bras Cienc. 1965;37:353-359.

18. Hunter JR, Leong R. The spawning energetics of female Northern anchovy Engraulis mordax. Fish. Bull. 1981; 79(2):215-230.
19. Cho Cho Latt. Observation on the fisheries of Anchovies (Engraulidae) of Setse coast. Unpublished MSc Thesis. Department of Marine Science, Mawlamyine University, Myanmar. 2010

20. Su Su Hlaing. Commercially important ichthyological fauna of the Thanlwin River mouth and adjacent sea. Unpublished MRes Thesis. Department of Marine Science, Mawlamyine University, Myanmar.2010.

21. Wongratana T. Diagnoses of 24 new species and proposal of a new name for a species of Indo-Pacific clupeoid fishes. Japan. J Ichthyol. $1983 ; 29(4): 385-407$.

22. Wongratana T. Four new species of clupeoid fishes (Clupeidae and Engraulidae) from Australian waters. Proc Biol Soc Wash. 1987;100(1):104-111.

23. Wongratana T. Two new species of anchovies of the genus Stolephorus (Engraulidae), with a key to species of Engraulis, Encrasicholina, and Stolephorus. Am Mus Novit 1987;2876:1-8 